\title{
Seed systems of Brachiaria species in intercropping with grain sorghum in the off-season*
}

\section{Sistemas de implantação de espécies de Brachiaria em consórcio com sorgo granífero na segunda safra}

\author{
Betson Antônio de Sousa Junior ${ }^{1}$ (1) (https://orcid.org/0000-0003-0376-0374) \\ Alessandro Guerra da Silva' (1) (https://orcid.org/0000-0002-9556-0312) \\ Camila Jorge Bernabé Ferreira ** (1) (https://orcid.org/0000-0001-5006-9661) \\ Katia Aparecida de Pinho Costa2 (1) (https://orcid.org/0000-0002-9555-5089) \\ Gustavo André Simon' (1) (https://orcid.org/0000-0001-6935-6580) \\ Keuly de Lollo Almeida' (1) (https://orcid.org/0000-0001-5686-1692)
}

\begin{abstract}
ABTRACT: The grain sorghum intercropped with Brachiaria provides the production of grains and dry mass in the off-season; however, there is a lack of information related to the implantation of these species. The objective of this study was to identify the best association of sorghum and Brachiaria in the production of grain and dry matter in the Brazilian Cerrado region. The experiment was conducted in Rio Verde, State of Goiás, in the experimental design of randomized blocks, in a $2 \times 3 \times 4+5$ factorial scheme, with four replications. Two sorghum hybrids (BRS 330 and DKB 551) associated to three Brachiaria species (Brachiaria brizantha cultivar Marandu, Brachiaria decumbens and Brachiaria ruziziensis) were evaluated in four systems of Brachiaria implantation (row, interrow, row + interrow of sorghum and spread). Additional treatments referred to the two sorghum monocrops and the three Brachiaria species. The sorghum and Brachiaria consortium resulted in a reduction in grain yield, but the Brachiaria implantation systems in the row, interrow and spread were the most promising. The sorghum hybrid DKB 551 was the most sensitive to the competition with Brachiaria, although there were no grain yield differences in the intercropping. The Brachiaria intercropped in the interrow and in the row + interrow, mainly with $B$. ruziziensis, were the most promising for the production of dry mass and total crude protein. The cultivation of Brachiaria intercropped with sorghum provided a greater contribution of dry mass in the off-season, an important fact for the no-tillage system in the agricultural production systems of the Brazilian Cerrado.
\end{abstract}

KEYWORDS: Brachiaria spp.; dry mass; grain yield; Sorghum bicolor.
RESUMO: O consórcio de sorgo granífero com braquiária proporciona a produção de grãos e massa seca na entressafra; contudo, há carência de informaçóes relacionadas à implantação dessas espécies. Sendo assim, este trabalho teve por objetivo identificar a melhor associação de sorgo granífero e braquiária na segunda safra para produção de grãos e massa seca na regiáo do Cerrado. O experimento foi conduzido em Rio Verde, Goiás, no delineamento experimental de blocos randomizados, em esquema fatorial $2 \times 3 \times 4+5$, com quatro repetiçóes. Foram avaliados dois híbridos de sorgo granífero (BRS 330 e DKB 551) associados a três espécies de Brachiaria (Brachiaria brizantha cultivar Marandu, Brachiaria decumbens e Brachiaria ruziziensis) em quatro sistemas de implantaçáo da braquiária (linha, entrelinha, linha + entrelinha do sorgo e a lanço). Os tratamentos adicionais referiam-se aos dois monocultivos de sorgo e às três espécies de braquiária. $\mathrm{O}$ consórcio de sorgo com braquiária ocasionou reduçáo no rendimento de grãos, porém os sistemas de implantação da braquiária na linha, entrelinha e a lanço foram os mais promissores. O híbrido de sorgo DKB 551 foi o mais sensível à competição com a braquiária, sem, contudo, haver diferenças de rendimento de grãos em consórcio. Os consórcios das braquiárias na entrelinha e na linha + entrelinha, principalmente com a $B$. ruziziensis, foram os mais promissores para produção de massa seca e proteína bruta total. O cultivo de braquiária com o sorgo proporcionou maior aporte de massa seca na entressafra, fato importante para o sistema de plantio direto nos sistemas de produção agrícola dos Cerrados.

PALAVRAS-CHAVE: Brachiaria spp.; massa seca; rendimento de grãos; Sorghum bicolor.

\footnotetext{
'Universidade de Rio Verde - Programa de Pós-graduação em Produção Vegetal - Rio Verde (GO), Brazil.

${ }^{2}$ Instituto Federal de Educação Ciência e Tecnologia Goiano - Programa de Pós-graduação em Ciências Agrárias - Agronomia - Rio Verde (GO), Brazil.

*This paper is part of the dissertation thesis of the first author.

**Corresponding author: camilajbferreira@gmail.com

Received on: 6/14/2019. Accepted on: 9/27/2020
} 


\section{INTRODUCTION}

With the growing need to increase the production of raw materials for animal feed in agro-industries, the cultivation of sorghum represents an excellent option in succession to soybeans, since the crop has the greater tolerance to drought (low and erratic rainfall), typical in the Brazilian Cerrado, as its main advantage in relation to corn (SILVA et al., 2015).

The use of intercropping annual crops with forage species has become an advantageous alternative for the sustainability of tropical agricultural systems (BORGHI et al., 2013). This increase is a result of the diversity of crops in the production system, essential for no-till. The straw from the diversification of species in the system should preferably contain a high $\mathrm{C} / \mathrm{N}$ ratio and, consequently, a lower decomposition rate. This is fundamental, mainly in the Cerrado, since the region is characterized by presenting climatic conditions in the spring-summer that cause a rapid decomposition of the straw present on the soil surface (ANDREOTTI et al., 2008).

The advantage of the simultaneous cultivation of Brachiaria species with a crop of economic value, such as sorghum, lies in the fact that these species have good adaptability, tolerance and resistance to biotic factors and present high dry matter production with high nutritional value, capable of meeting the demand of animals, especially in the dry season of the year (FLÁVIO NETO et al., 2015). Therefore, the intercrop of grasses with Brachiaria appears as an option for the recovery of pastures, especially in regions with water restrictions, thus reducing expenses with restoration of the area. Moreover, the system provides increases in soybean grain yield when grown in succession to crops in the intercropping system (OLIVEIRA et al., 2017). Additionally, the use of intercropping has several advantages related to the reduction of weed infestation with the possibility of reducing the use of herbicides in the successor crop (OLIVEIRA JUNIOR et al., 2014), less erosion and greater soil cover, in addition to increase water use efficiency.

Despite this, there are reports in the literature on decreased yield of sorghum crop due to competition for resources from the environment with the intercropped species (SILVA et al., 2014; HORVATHY NETO et al., 2014; RIBEIRO et al., 2015). In this sense, there is a need to optimize the conditions of the environment in order to achieve higher productivity in this system, in addition to the benefits for sustainability and for the successor crop (IQBAL et al., 2019). Added to this, there is little research on the cultivation of sorghum intercropped with Brachiaria, which justify the need to improve techniques for implantation of Brachiaria to identify those that provide less competition between plants in the off-season. Thus, there would be greater use and benefits of these systems as alternatives for the formation of straw in the Cerrados.

In this sense, the hypothesis established in this study is that the different forms of implantation of Brachiaria species, as well as sorghum hybrids respond differently in terms of grain and dry matter production. Thus, the objective of this study was to evaluate the combination of grain sorghum with Brachiaria species in different intercropping systems for the production of grains and dry matter in the off-season.

\section{MATERIAL AND METHODS}

The experiment was conducted in the field, in the municipality of Rio Verde, state of Goiás, (17047'24.5"S; 5057'41.7”W; and $769 \mathrm{~m}$ altitude) on soil classified as dystrophic red Latosol according to the Brazilian classification (EMBRAPA, 2018), grown in no-till system in the off-season of 2012. The results of the soil chemical and physical properties in the $0.0-0.2 \mathrm{~m}$ layer were: $\mathrm{pH}$ in $\mathrm{CaCl}_{2}: 5.0$; Ca: $1.01 ; \mathrm{Mg}: 0.77 ; \mathrm{K}: 0.42 ; \mathrm{Al}$ : 0.06; $\mathrm{H}+\mathrm{Al}$ : 4.0 ; cation exchange capacity: 6.2 ; and sum of bases: 2.08 , in $\mathrm{cmol}_{\mathrm{c}} \cdot \mathrm{dm}^{-3} ; \mathrm{P}: 2.08 \mathrm{mg} \cdot \mathrm{dm}^{-3}$; base saturation: 35.01 ; Al saturation: $2.72 \%$; organic matter: $37.09 \mathrm{~g} \cdot \mathrm{dm}^{-3}$; clay: $560 \mathrm{~g} \cdot \mathrm{kg}^{-1}$; silt: $110 \mathrm{~g} \cdot \mathrm{kg}^{-1}$ and sand: $330 \mathrm{~g} \cdot \mathrm{kg}^{-1}$. Data on temperature and rainfall during the experimental period are in Fig. 1.

The experiment was a $2 \times 3 \times 4+5$ factorial randomized block design, with four repetitions. Two hybrids of grain sorghum, with differences in yield potential, were recommended for cultivation in the Central-West region: BRS 330 (early cycle, red colored grains without tannin, medium production potential) and DKB 551 (early cycle, cream colored grains without tannin, high production potential) combined with three species of Brachiaria (Brachiaria brizantha cultivar Marandu, Brachiaria decumbens and Brachiaria ruziziensis) in four Brachiaria planting systems (intercrop in the sorghum sowing row, in the interrow, in the row and interrow, and broadcast sowing). The additional treatments were related to monocrops of the two sorghum hybrids and the three species of Brachiaria. Plots consisted of four rows of $5.0 \mathrm{~m}$, spaced $0.5 \mathrm{~m}$ apart, the two central rows considered as useful area, disregarding $0.5 \mathrm{~m}$ from each end $\left(4.0 \mathrm{~m}^{2}\right)$.

One week before the onset of the experiment, after the soybean harvest, weeds were desiccated, $720 \mathrm{~g}$ a.e. ha $^{-1}$ glyphosate with a flow volume of $150 \mathrm{l} \cdot \mathrm{ha}^{-1}$. Brachiaria was planted on the same day as sorghum, both in intercrop and monocrop, taking into account the number of viable pure seeds, considering germination of 40,52 and $66 \%$, for $B$. decumbens, B. brizantha and $B$. ruziziensis, respectively.

The day before sowing, furrowing was performed, and fertilizer was applied in the sorghum sowing row, the equivalent to $300 \mathrm{~kg} \cdot \mathrm{ha}^{-1} \mathrm{NPK}$ : 02-20-18. For the sowing of Brachiaria in the interrow, the furrows were opened manually. Both crops were sown manually at $2 \mathrm{~cm}$ depth on March 8 . In the broadcast sowing system, Brachiaria seeds were scattered in the plots before closing the sorghum sowing furrows. 


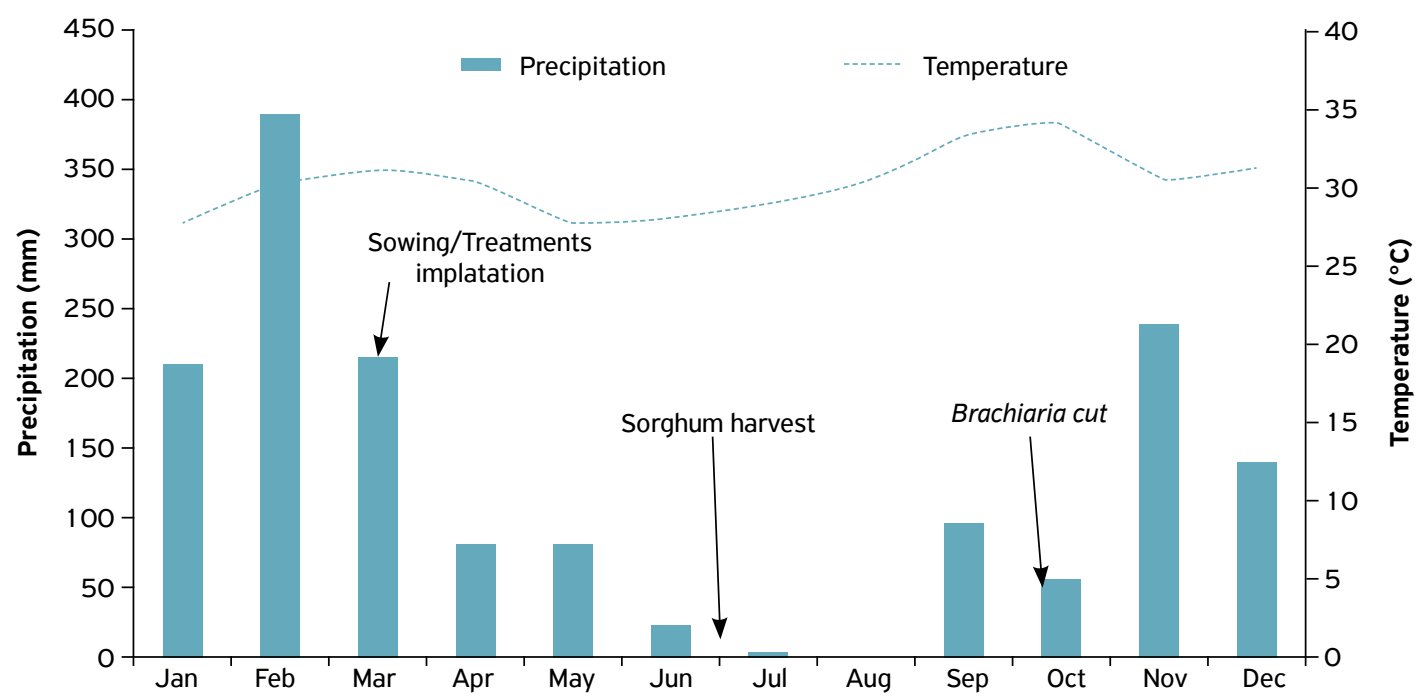

Figure 1. Values of average air temperature and precipitation from January to December 2012, Rio Verde-GO. Source: Climatological Station of the Universidade de Rio Verde.

At 25 days after emergence (DAE) of sorghum seedlings, $100 \mathrm{~kg} \mathrm{~N} \cdot \mathrm{ha}^{-1}$ was applied, as urea source. On this date, sorghum was thinned to population equivalent to 180,000 plants.ha $^{-1}$.

For weed control in postemergence, a manual weeding was performed at 25 DAE. For pest management, the mechanized application of the methomyl insecticide $\left(0.61 \cdot \mathrm{ha}^{-1}\right.$ in a flow volume of $150 \mathrm{l} \cdot \mathrm{ha}^{-1}$ ) was carried out.

At 115 DAE, sorghum was harvested from the useful area of the plots, and evaluated for grain yield (panicles were harvested, and threshed, grains were weighed, with moisture corrected to $13 \%$, converting the data to $\left.\mathrm{kg} \cdot \mathrm{ha}^{-1}\right)$; thousand grain weight (weighing a thousand grains with moisture corrected to 13\%); plant height (measurement from the base to the end of the panicle in five plants chosen at random); tillering index (counting the number of tillers in five plants chosen at random) and plant population.

Brachiaria remained in the field until 90 days after the sorghum harvest, being evaluated, at that time, plant height (measurement from the base to the end of the last fully expanded leaf in five plants chosen at random) and the tillering index (counting the number of tillers in five plants).

Upon Brachiaria harvest, the total dry matter yield was also evaluated, collecting at two points of the plot, using an iron square with $0.5 \times 0.5 \mathrm{~m}\left(0.25 \mathrm{~m}^{2}\right)$. Subsequently, samples were taken to a forced air oven at $65^{\circ} \mathrm{C}$ to constant weight, the dry matter was determined and transformed to $\mathrm{kg} \cdot \mathrm{ha}^{-1}$. In the same sample, nitrogen and crude protein contents were determined, according to the methodology described by MALAVOLTA et al. (1997). Organic carbon was also evaluated by burning the samples in a muffle furnace at $550^{\circ} \mathrm{C}$ (EMBRAPA, 2017). From this, the $\mathrm{C} / \mathrm{N}$ ratio of each species was determined.
The percentage of vegetation cover on the soil surface was evaluated upon sorghum harvest. This assessment was carried out in two places in the useful area of the plots using a $0.5 \times 0.5 \mathrm{~m}\left(0.25 \mathrm{~m}^{2}\right)$ iron square containing a line marked with ten equidistant points. The quantification of vegetation cover was performed when these points coincided with the presence of vegetation cover.

Data were tested by analysis of variance and when significant, the Tukey's test at $5 \%$ probability was applied to compare the means within the intercropping and the monocrop. To compare the mean values obtained between these planting systems, the Dunnett's test at 5\% probability was used.

\section{RESULTS AND DISCUSSION}

\section{Sorghum crop}

The results of the analysis of variance for sorghum grain yield indicate significance for the sources of variation planting system, Brachiaria, intercropping $\times$ monocrop, and monocrop (Table 1).

The Brachiaria planting systems in the row, interrow and broadcast sowing provided the highest sorghum grain yield, being superior to the row + interrow system (Table 2). These results suggest that the row + interrow system resulted in better distribution of Brachiaria plants in the area. This caused the Brachiaria plants to occupy the cultivation area more rapidly than in the other systems, favoring greater competition with sorghum plants and lower grain yield, as also reported by BORGHI; CRUSCIOL (2007). 
Table 1. Results of the analysis of variance of the variables yield (Y), thousand grain mass (M1OOOG), sorghum height (SH), plant population (POP) and $\mathrm{C} / \mathrm{N}$ ratio $(\mathrm{C} / \mathrm{N})$ of the sorghum crop, height of plants $(\mathrm{BH})$, tillering index $(\mathrm{TI})$ and $\mathrm{C} / \mathrm{N}$ ratio $(\mathrm{C} / \mathrm{N})$ of $B$ rachiaria, dry mass yield (DMY), total crude protein (TCP) and soil cover (CS) of sorghum + Brachiaria in different implantation systems in the grain sorghum intercropped with B. brizantha $(\mathrm{Bb}), B$. decumbens (Bd) and B. ruziziensis (Br) in the off-season in Rio Verde/GO, 2012.

\begin{tabular}{|c|c|c|c|c|c|c|c|c|c|c|c|c|c|c|}
\hline \multirow{2}{*}{ Variation sources } & \multicolumn{6}{|c|}{ Sorghum } & \multicolumn{4}{|c|}{ Brachiaria } & \multicolumn{4}{|c|}{ Sorghum + Brachiaria } \\
\hline & DF & $\mathbf{Y}$ & M1000G & SH & POP & $\mathrm{C} / \mathrm{N}$ & DF & BH & TI & $\mathrm{C} / \mathrm{N}$ & DF & DMY & TCP & CS \\
\hline Blocks & 3 & & & & & & 3 & & & & 3 & & & \\
\hline Hybrids & 1 & ns & ** & ns & ns & ** & 1 & ns & ns & ns & 1 & ns & ns & ns \\
\hline $\begin{array}{l}\text { Implantation } \\
\text { systems }\end{array}$ & 3 & ** & ** & * & ** & ns & 3 & ns & * & ns & 3 & ** & ** & ns \\
\hline Brachiaria spp. & 2 & ** & ** & ns & ns & ns & 2 & ** & $* *$ & $* *$ & 2 & $* *$ & ** & ns \\
\hline Hybrids $\times$ systems & 3 & ns & ns & ns & ns & ns & 3 & ns & ns & ns & 3 & ns & ns & ns \\
\hline $\begin{array}{l}\text { Hybrids } \times \\
\text { Brachiaria spp. }\end{array}$ & 2 & ns & ns & ns & ns & ns & 2 & ns & ns & ns & 2 & ns & ns & ns \\
\hline $\begin{array}{l}\text { Systems × } \\
\text { Brachiaria spp. }\end{array}$ & 6 & ns & ns & ns & ns & ns & 6 & * & ns & ns & 6 & $* *$ & ** & ns \\
\hline $\begin{array}{l}\text { Hybrids } \times \text { Syst. } \\
\times \text { Brac. }\end{array}$ & 6 & ns & ns & ns & ns & ns & 6 & ns & ns & ns & 6 & ns & ns & ns \\
\hline $\begin{array}{l}\text { Intercropping } \\
\times \text { monocrop }\end{array}$ & 1 & ** & $* *$ & ** & $* *$ & ns & 1 & ** & $* *$ & $* *$ & 1 & ** & ** & ** \\
\hline Monocrop & 1 & * & ** & ns & ns & $* *$ & 2 & $* *$ & * & $* *$ & 4 & $* *$ & ** & ** \\
\hline CV (\%) & & 19.5 & 8.9 & 6.3 & 18.0 & 18.4 & & 5.0 & 16.7 & 10.7 & & 9.8 & 12.2 & 8.1 \\
\hline
\end{tabular}

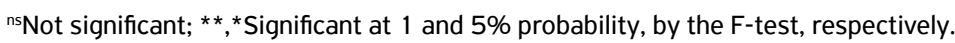

The Brachiaria planting system in the row was expected to cause a decrease in sorghum yield when compared to the interrow, as observed by RIBEIRO et al. (2015). Probably the significant decrease in rainfall after the implementation of the experiment (Fig. 1) combined with the faster emergence of sorghum compared to Brachiaria seedlings, caused the delay in forage establishment (MAGALHÂES et al., 2000). This favored the closing of the rows and the shading of Brachiaria plants in both systems.

In the intercrop, the highest grain yields were obtained with the use of B. brizantha and $B$. decumbens, which resulted in an increase of approximately $500 \mathrm{~kg} \cdot \mathrm{ha}^{-1}$ compared to the yield of sorghum intercropped with B. ruziziensis (Table 2). For presenting stoloniferous growth with high emergence of tillers and leaves, B. ruziziensis showed higher competition for space with the sorghum crop, thus causing lower grain yield (SILVA et al., 2014). It is worth noting that, unlike what is done in intercropping corn and Brachiaria with application of underdoses of graminicides, specifically nicosulfuron, for the suppression of Brachiaria, in the present study, herbicide was not applied in postemergence, since sorghum also has no selectivity to graminicides (HENNIGH et al., 2010).

The grain yields of the two sorghum hybrids in the intercropping system did not differ from each other (Table 1), being lower than the respective monocrops (Table 2). This can be ascribed to the competition between the two species in the intercropping system, as found in other studies (SILVA et al., 2014; HORVATHY NETO et al., 2014; RIBEIRO et al., 2015).
Even with a reduction in grain yield, the importance of the intercropping system should be emphasized for the production of grains and dry matter for soil cover in the off-season, favoring the diversification of crops on the property, in addition to the benefits provided for the subsequent crop.

In monocrop, DKB 551 had the best performance (Table 2), highlighting the excellent productive potential of both hybrids, above the national average for the cultivation of sorghum in the Central-West Region (CONAB, 2012). On the other hand, the absence of differences in grain yield for sorghum hybrids in the intercropping system proves the higher sensitivity to competition between DKB 551 and Brachiaria plants. This meant that there was a reduction in grain yield of the hybrid in question, consequently resembling that of BRS 330 , with lower production potential.

For the mass of thousand-grain, there was significance for the same sources of variation of the variable previously analyzed, in addition to the effect of sorghum hybrids $(\mathrm{p}<0.01)$ (Table 1). Both in the intercropping system and in monocrop, DKB 551 showed the highest value, which may justify the higher yield, as well as the interrow sowing system (Table 2). In this case, there was less competition with sorghum, especially at the early stages of development, thus favoring the higher weight of grains.

Intercropping with $B$. decumbens, independent of the sorghum hybrid, provided the highest mass of thousand grain, in contrast to the values obtained for $B$. brizantha and B. ruziziensis (Table 2). It is noteworthy that $B$. brizantha 
Table 2. Means values of grain yield and mass of thousand grains, height, plant population and $\mathrm{C} / \mathrm{N}$ ratio of the sorghum culture in different implantation systems in the grain sorghum intercropped with $B$. brizantha $(\mathrm{Bb}), B$. decumbens $(\mathrm{Bd})$ and $B$. ruziziensis $(\mathrm{Br})$ in the off-season in Rio Verde/GO, 2012.

\begin{tabular}{|c|c|c|c|c|c|c|c|}
\hline \multirow{3}{*}{$\begin{array}{l}\text { Implantation } \\
\text { systems }\end{array}$} & \multicolumn{6}{|c|}{ Grain yield $\left(\mathrm{kg} \cdot \mathrm{ha}^{-1}\right)$} & \multirow{3}{*}{ Mean } \\
\hline & \multicolumn{3}{|c|}{ BRS 330} & \multicolumn{3}{|c|}{ DKB 551} & \\
\hline & $B b$ & Bd & $B r$ & $B b$ & $B d$ & $\mathrm{Br}$ & \\
\hline Row & $2,225^{*}$ & $2,548^{*}$ & $2,100^{*}$ & $2,597^{*}$ & $2,785^{*}$ & $2,314^{*}$ & $2,428 a$ \\
\hline Interrow & $2,314^{*}$ & $2,863^{*}$ & $1,820^{*}$ & $2,710^{*}$ & $2,949^{*}$ & $2,305^{*}$ & $2,493 a$ \\
\hline Row + interrow & $2,293^{*}$ & $2,219^{*}$ & $1,834^{*}$ & $2,258^{*}$ & $1,795^{*}$ & $1,343^{*}$ & $1,957 b$ \\
\hline \multirow[t]{2}{*}{ Broadcast } & $2,317^{*}$ & $2,239^{*}$ & $2,251^{*}$ & $3,113^{*}$ & $2,559^{*}$ & $1,765^{*}$ & $2,374 a$ \\
\hline & \multicolumn{2}{|c|}{$B b$} & \multicolumn{2}{|c|}{$B d$} & \multicolumn{2}{|c|}{$\mathrm{Br}$} & \\
\hline \multirow[t]{2}{*}{ Brachiaria } & \multicolumn{2}{|c|}{$2,478 \mathrm{~A}$} & \multicolumn{2}{|c|}{$2,495 \mathrm{~A}$} & \multicolumn{2}{|c|}{$1,966 \mathrm{~B}$} & 2,313 \\
\hline & \multicolumn{3}{|c|}{ BRS 330} & \multicolumn{3}{|c|}{ DKB 551} & \\
\hline Intercropping & \multicolumn{3}{|c|}{$2,252 \mathrm{~A}$} & \multicolumn{3}{|c|}{$2,374 \mathrm{~A}$} & \\
\hline Monocrop & \multicolumn{3}{|c|}{$4,756 \mathrm{~B}$} & \multicolumn{3}{|c|}{$5,510 \mathrm{~A}$} & 5,133 \\
\hline & & & ass of the & d grains & & & \\
\hline Implantation & & BRS 330 & & & DKB 551 & & Mean \\
\hline & $B b$ & $B d$ & $B r$ & $B b$ & $B d$ & $\mathrm{Br}$ & \\
\hline Row & 14.72 & 16.36 & 14.03 & 17.95 & 20.93 & 17.86 & $16.97 \mathrm{~b}$ \\
\hline Interrow & 16.74 & 18.32 & 14.64 & 18.45 & 21.87 & 18.59 & $18.10 \mathrm{a}$ \\
\hline Row+ interrow & $11.33^{*}$ & 15.76 & $10.90^{*}$ & 15.47 & 20.65 & 15.17 & $14.88 b$ \\
\hline Broadcast & 13.03 & 15.88 & 14.62 & 17.93 & 20.84 & 17.88 & $16.63 \mathrm{~b}$ \\
\hline & & & & & & & \\
\hline Brachiaria & & & & & & & \\
\hline & & BRS 330 & & & DKB 551 & & \\
\hline Intercropping & & $14.44 \mathrm{~B}$ & & & $18.63 \mathrm{~A}$ & & \\
\hline Monocrop & & $17.69 \mathrm{~B}$ & & & $23.66 \mathrm{~A}$ & & \\
\hline & & & $\mathrm{He}$ & m) & & & \\
\hline $\begin{array}{l}\text { Implantation } \\
\text { systems }\end{array}$ & & BRS 330 & & & DKB 551 & & Mean \\
\hline & $B b$ & $B d$ & $B r$ & $B b$ & $B d$ & $\mathrm{Br}$ & \\
\hline Row & 1.09 & 1.10 & 1.14 & 1.10 & 1.09 & 1.13 & $1.11 \mathrm{ab}$ \\
\hline Interrow & 1.14 & 1.13 & 1.10 & 1.13 & 1.09 & 1.15 & $1.12 \mathrm{a}$ \\
\hline Row+ interrow & 1.12 & 1.12 & 1.10 & 1.15 & 1.12 & 1.19 & $1.12 \mathrm{a}$ \\
\hline Broadcast & $1.06^{*}$ & $1.06^{*}$ & $1.07^{*}$ & $1.08^{*}$ & 1.09 & $1.02^{*}$ & $1.06 \mathrm{~b}$ \\
\hline & & BRS 330 & & & DKB 551 & & \\
\hline Monocrop & & $1.17 \mathrm{~A}$ & & & $1.18 \mathrm{~A}$ & & \\
\hline & & Plar & opulation & $0.000 \mathrm{pl}$ & $\left.1 a^{-1}\right)$ & & \\
\hline Implantation & & BRS 330 & & & DKB 551 & & Mean \\
\hline & $B b$ & $B d$ & $\mathrm{Br}$ & $B b$ & $B d$ & $B r$ & \\
\hline Row & $16.00^{*}$ & $14.86^{*}$ & $15.36^{*}$ & $14.84^{*}$ & $14.37^{*}$ & $13.88^{*}$ & $14.88 b$ \\
\hline Interrow & 17.50 & 16.95 & 17.14 & 17.15 & $16.08^{*}$ & 17.22 & $17.00 \mathrm{a}$ \\
\hline Row + interrow & $15.69^{*}$ & $14.58^{*}$ & $15.69^{*}$ & $14.30^{*}$ & $13.61^{*}$ & $13.47^{*}$ & $14.55 b$ \\
\hline Broadcast & $15.83^{*}$ & $14.73^{*}$ & $14.61^{*}$ & $15.37^{*}$ & $16.04^{*}$ & $15.42^{*}$ & $15.33 b$ \\
\hline & & BRS 330 & & & DKB 551 & & \\
\hline Monocrop & & $17.76 \mathrm{~A}$ & & & $17.90 \mathrm{~A}$ & & \\
\hline & & & & & & & \\
\hline Implantation & & BRS 330 & & & DKB 551 & & Mean \\
\hline & $B b$ & $B d$ & $\mathrm{Br}$ & $B b$ & $B d$ & $\mathrm{Br}$ & \\
\hline Row & 67.31 & 65.48 & 66.37 & 58.73 & 59.36 & 55.57 & \\
\hline Interrow & 64.17 & 65.64 & 63.21 & 57.37 & 61.77 & 58.02 & \\
\hline Row+ interrow & 66.74 & 64.04 & 67.63 & 59.52 & 59.58 & 57.49 & \\
\hline Broadcast & 63.49 & 67.16 & 64.23 & 57.83 & 61.94 & 60.45 & \\
\hline & & BRS 330 & & & DKB 551 & & \\
\hline Intercropping & & $64.45 \mathrm{~A}$ & & & $59.67 \mathrm{~B}$ & & \\
\hline Monocrop & & $65.45 \mathrm{~A}$ & & & $58.96 \mathrm{~B}$ & & \\
\hline
\end{tabular}

*Means followed by the same letters, uppercase on the line and lowercase on the column, do not differ by the Tukey test at $5 \%$ probability.

${ }^{*},{ }^{n S}$ Significant at $5 \%$ probability and not significant, respectively, by the Dunnett's test in relation to monocrop. 
and $B$. ruziziensis in the row + interrow system with the BRS 330 hybrid were the only combinations that caused a reduction in mass of thousand grain compared to the sorghum monocrop. Due to the greater competition between species for environmental resources, mainly water, whose availability significantly decreases with sorghum development in the off-season, less translocation of photoassimilates to fill sorghum grains may have occurred. This fact contributed to the formation of grains with less weight.

Broadcast sowing Brachiaria resulted in lower height of sorghum plants compared to the interrow and row + interrow systems (Table 2). Besides that, broadcast sowing by haul caused a reduction in the size of sorghum compared to monocrop (except for the combination of DKB 551 with B. decumbens). Important, taller plants accumulate more biomass and, consequently, more nutrients. These are translocated to grains during the filling phase. Thus, after harvesting, these plants can contribute with a greater amount of straw on the soil and nutrient cycling.

The final population of sorghum plants was affected by the sowing systems and by the intercropping $\times$ monocrop interaction (Table 1). The distribution of Brachiaria plants in the interrow of sorghum caused less competition in the establishment of the crop, as reported for corn (BORGHI; CRUSCIOL, 2007) and sorghum (HORVATHY NETO et al., 2014). Additionally, this Brachiaria sowing system was the only one that provided similar results to the respective sorghum monocrops, except for DKB 551 intercropped with $B$. decumbens (Table 2). According to CRISPIM; BRANCO (2002), this species develops well in less fertile soils, such as the one in the present study. This led to greater competition with DKB 551, with higher production potential compared to BRS 330, and consequently more sensitive to competition; Brachiaria was sown on the same date as the sorghum, which favored the suppression of the development of sorghum seedlings.

The $\mathrm{C} / \mathrm{N}$ ratio showed, in general, higher value for the hybrid BRS 330 compared to DKB 551, both in the intercropping system and in monocrop (Table 2). In the Cerrado, the decomposition of straw on the soil surface is greater, due to the higher average temperature in the off-season, in relation to regions of temperate climate, this being attributed to the favorable conditions for decomposition (SILVA et al., 2015). Therefore, straw production in the Cerrados to maintain the no-till system becomes a challenge. Sorghum hybrids with a higher $\mathrm{C} / \mathrm{N}$ ratio, due to the higher proportion of lignified material (stems), provide greater persistence of straw on the soil surface, providing beneficial effects for soil conservation.

\section{Brachiaria crop}

Intercropping with sorghum influenced the development (plant height) of Brachiaria, with significance detected for the system $\times$ Brachiaria interaction and for the intercrop $\times$ monocrop interaction (Table 1). All sowing systems, independent of the sorghum hybrid, promoted the suppression of $B$. brizantha, the same being observed for $B$. decumbens when sown in the row and in the interrow of sorghum (Table 3). For B. ruziziensis, there were no significant differences in plant height between intercrop and monocrop. This can be justified by the prostrate growth habit of the forage species in question (SILVA et al., 2014).

Due to the morphological differences of the forage species, a higher height of $B$. brizantha was found, whose value was similar to that of $B$. ruziziensis in the row and interrow intercropping systems (Table 3). The larger size of B. brizantha, both in intercrop and monocrop, is justified by the habit of growing erect or semierect (ALVIM et al., 2002). For this species, the sowing systems did not influence the size of the plants, whereas for $B$. decumbens, the highest value was observed in the broadcast sowing, and for B. ruziziensis, in the other planting systems.

Another variable affected by the intercropping sowing systems was the Brachiaria tillering index (Table 1). This characteristic is directly related to dry matter production (SANTOS et al., 2009). The lowest tillering values registered in the intercrop (Table 3) is attributed to the effect of shading and competition of sorghum plants with Brachiaria, regardless of the planting system and forage species. During the development of sorghum crop, shading suppresses the emergence of tillers in axillary buds (TAIZ et al., 2017) as occurred in Brachiaria.

The highest tillering value was found in the row + interrow intercropping system (Table 3). This is attributed to the better distribution of plants in the area, which favors the incidence of radiation on the basal buds, thus inducing tillering. The number of seeds was the same for all systems and in the broadcast sowing, only Brachiaria seeds that were in the sorghum sowing furrow were covered with soil, which did not occur with the others. Once exposed to radiation, seeds are easier to lose water to the atmosphere, which negatively affects the establishment of seedlings. Still, B. ruziziensis had the highest tillering capacity, both in intercrop and monocrop, similar to that observed in other studies (HORVATHY NETO et al., 2012; SILVA et al., 2014).

The $\mathrm{C} / \mathrm{N}$ ratio of Brachiaria was lower in the intercropping systems, except for sowing in the row + interrow for B. ruziziensis intercropped with DKB 551 (Table 3), the same pattern observed by other authors (GIACOMINI et al., 2003; DONEDA et al., 2012). Despite the decrease in the $\mathrm{C} / \mathrm{N}$ ratio in intercropping systems, the benefits related to the addition of dry matter with the cultivation of Brachiaria in the intercrop have advantages in soil conservation (FLÁVIO NETO et al., 2015) and weed control (OLIVEIRA JUNIOR et al., 2014).

\section{Sorghum and Brachiaria crops}

In the analysis of the dry matter yield of sorghum and Brachiaria, the interaction of sowing systems and Brachiaria was significant $(\mathrm{p}<0.01)$ (Table 1). In sowing systems, on average, intercrop with $B$. decumbens resulted in the lowest dry matter value (Table 4). When sowing systems are involved, B. ruziziensis 
Table 3. Means values of plant height and tillering index of the Brachiaria culture in different implantation systems in the intercropping of grain sorghum with B. brizantha $(\mathrm{Bb}), B$. decumbens $(\mathrm{Bd})$ and $B$. ruziziensis $(\mathrm{Br})$ in the off-season Rio Verde/GO, 2012.

\begin{tabular}{|c|c|c|c|c|c|c|c|}
\hline \multirow{3}{*}{$\begin{array}{l}\text { Implantation } \\
\text { systems }\end{array}$} & \multicolumn{6}{|c|}{ Plant height (m) } & \multirow{3}{*}{ Mean } \\
\hline & \multicolumn{3}{|c|}{ BRS 330} & \multicolumn{3}{|c|}{ DKB 551} & \\
\hline & $B b$ & $B d$ & $\mathrm{Br}$ & $B b$ & $B d$ & $B r$ & \\
\hline Row & $1.09^{*}$ & $0.59^{*}$ & 1.04 & $1.06^{*}$ & $0.57^{*}$ & 1.08 & \\
\hline Interrow & $1.08^{*}$ & $0.59^{*}$ & 1.04 & $1.09^{*}$ & $0.60^{*}$ & 1.06 & \\
\hline Row + interrow & $1.12^{*}$ & 0.66 & 1.12 & $1.09^{*}$ & 0.69 & 1.05 & \\
\hline \multirow[t]{2}{*}{ Broadcast } & $1.09^{*}$ & 0.63 & 1.03 & $1.11^{*}$ & 0.62 & 1.04 & \\
\hline & \multicolumn{2}{|c|}{$B b$} & \multicolumn{2}{|c|}{$B d$} & \multicolumn{2}{|c|}{$\mathrm{Br}$} & \\
\hline \multirow[t]{2}{*}{ Brachiaria } & \multicolumn{2}{|c|}{$1.09 \mathrm{~A}$} & \multicolumn{2}{|c|}{$0.61 \mathrm{C}$} & \multicolumn{2}{|c|}{$1.05 \mathrm{~B}$} & \\
\hline & \multicolumn{2}{|c|}{$B b$} & \multicolumn{2}{|c|}{$B d$} & \multicolumn{2}{|c|}{$\mathrm{Br}$} & \\
\hline Row & \multicolumn{2}{|c|}{$1.07 \mathrm{Aa}$} & \multicolumn{2}{|c|}{$0.57 \mathrm{Bb}$} & \multicolumn{2}{|c|}{$1.06 \mathrm{Aa}$} & \\
\hline Interrow & \multicolumn{2}{|c|}{$1.08 \mathrm{Aa}$} & \multicolumn{2}{|c|}{$0.60 \mathrm{Bb}$} & \multicolumn{2}{|c|}{$1.05 \mathrm{Aa}$} & \\
\hline Row + interrow & \multicolumn{2}{|c|}{$1.10 \mathrm{Aa}$} & \multicolumn{2}{|c|}{$0.67 \mathrm{Bb}$} & \multicolumn{2}{|c|}{$1.08 \mathrm{Ba}$} & \\
\hline Broadcast & \multicolumn{2}{|c|}{$1.09 \mathrm{Aa}$} & \multicolumn{2}{|c|}{$1.00 \mathrm{Ba}$} & \multicolumn{2}{|c|}{$0.62 \mathrm{Cb}$} & \\
\hline Monoculture & & & & & & & \\
\hline & & & Tille & dex & & & \\
\hline $\begin{array}{l}\text { Implantation } \\
\text { systems }\end{array}$ & & BRS 330 & & & DKB 551 & & Mean \\
\hline & $B b$ & $B d$ & $B r$ & $B b$ & $B d$ & $B r$ & \\
\hline Row & $14.8^{*}$ & $17.3^{*}$ & $24.0^{*}$ & $15.3^{*}$ & $18.3^{*}$ & $23.8^{*}$ & $18.8 b$ \\
\hline Interrow & $14.5^{*}$ & $19.0^{*}$ & $23.3^{*}$ & $15.3^{*}$ & $20.0^{*}$ & $25.3^{*}$ & $19.6 b$ \\
\hline Row + interrow & 17.1 & 23.5 & $25.5^{*}$ & 18.0 & 24.0 & $26.5^{*}$ & $22.4 \mathrm{a}$ \\
\hline Broadcast & $14.3^{*}$ & $18.8^{*}$ & $23.5^{*}$ & $14.8^{*}$ & $19.3^{*}$ & $24.5^{*}$ & $19.2 b$ \\
\hline & & & & & & & \\
\hline Intercropping & & & & & & & \\
\hline Monoculture & & & & & & & \\
\hline & & & & & & & \\
\hline $\begin{array}{l}\text { Implantation } \\
\text { svstems }\end{array}$ & & BRS 330 & & & DKB 551 & & Mean \\
\hline & $B b$ & $B d$ & $\mathrm{Br}$ & $B b$ & $B d$ & $B r$ & \\
\hline Row & $35.48^{*}$ & $28.09^{*}$ & $29.82^{*}$ & $33.37^{*}$ & $30.02^{*}$ & $26.49^{*}$ & \\
\hline Interrow & $37.04^{*}$ & $31.15^{*}$ & $25.20^{*}$ & $34.56^{*}$ & $26.91^{*}$ & $22.92^{*}$ & \\
\hline Row + interrow & $34.12^{*}$ & $28.72^{*}$ & $29.07^{*}$ & $36.72^{*}$ & $28.04^{*}$ & 35.59 & \\
\hline Broadcast & $36.45^{*}$ & $30.89^{*}$ & $27.72^{*}$ & $35.63^{*}$ & $26.15^{*}$ & $25.98^{*}$ & \\
\hline & $B b$ & & $B d$ & & $B r$ & & \\
\hline Intercropping & $33.54 \mathrm{~A}$ & & $28.74 \mathrm{~B}$ & & $27.84 \mathrm{~B}$ & & \\
\hline Monoculture & $45.58 \mathrm{~A}$ & & $36.49 \mathrm{~B}$ & & $37.49 \mathrm{~B}$ & & \\
\hline
\end{tabular}

*Means followed by the same letters, uppercase on the line and lowercase on the column, do not differ by the Tukey's test at $5 \%$ probability. *, ns Significant at $5 \%$ probability and not significant, respectively, by the Dunnett's test in relation to monocrop.

provided higher dry matter yields, similar to the values obtained with $B$. brizantha sown in the row and by broadcast.

Brachiaria sowed in the interrow and row + interrow provided higher dry matter values (Table 4). The fact that there are no Brachiaria plants in the sorghum row (interrow intercrop), or with a reduced population (row + interrow system) may have caused a decrease in plant competition, favoring at first the growth of sorghum and later the growth of Brachiaria, after harvesting the cereal.

The advantage of adopting the intercrop of grain sorghum with Brachiaria in the off-season can be seen with the values obtained 
Table 4. Mean values of dry mass yield, total crude protein and soil cover in different implantation systems intercropped of grain sorghum with Brachiaria brizantha (Bb), B. decumbens (Bd) and B. ruziziensis (Br) in the off-season in Rio Verde-G0, 2012.

\begin{tabular}{|c|c|c|c|c|c|c|c|}
\hline \multirow{3}{*}{$\begin{array}{l}\text { Implantation } \\
\text { systems }\end{array}$} & \multicolumn{6}{|c|}{ Dry mass yield $\left(\mathrm{kg} \cdot \mathrm{ha}^{-1}\right)$} & \multirow{3}{*}{ Mean } \\
\hline & \multicolumn{3}{|c|}{ BRS 330} & \multicolumn{3}{|c|}{ DKB 551} & \\
\hline & $B b$ & $B d$ & $B r$ & $B b$ & $B d$ & $B r$ & \\
\hline Row & $5,836^{* 1, * 2}$ & $4,258^{* 1, * 2}$ & $6,499 * 1, * 2$ & $5,989^{* 1, * 2}$ & $4,563^{* 1, * 2}$ & $6,923^{* 1 . * 2}$ & $5,678 b$ \\
\hline Interrow & $6,604^{* 1, * 2}$ & $5,908^{* 1, * 2}$ & $7,302^{* 1, * 2}$ & $6,969^{* 1, * 2}$ & $6,037^{* 1, * 2}$ & $7,771^{* 1 . * 2}$ & $6,765 a$ \\
\hline Row + interrow & $6,861^{* 1, * 2}$ & $5,711^{* 1, * 2}$ & $7,854^{* 1, * 2}$ & $7,031^{* 1, * 2}$ & $6,057^{\star 1, * 2}$ & $8,017^{* 1 . * 2}$ & $6,921 \mathrm{a}$ \\
\hline \multirow[t]{2}{*}{ Broadcast } & $4,746^{* 1, * 2}$ & $4,218^{* 1, * 2}$ & $5,385^{* 1, * 2}$ & $4,898^{* 1, * 2}$ & $4,131^{* 1, * 2}$ & $5,552^{* 1 . * 2}$ & $4,821 \mathrm{c}$ \\
\hline & $B b$ & \multicolumn{3}{|c|}{$B d$} & \multicolumn{2}{|l|}{$B r$} & \\
\hline Row & 5,913 Aab & \multicolumn{3}{|c|}{$4,411 \mathrm{Bb}$} & \multicolumn{2}{|l|}{ 6,711 Aab } & \\
\hline Interrow & $6,787 \mathrm{Ba}$ & \multicolumn{3}{|c|}{$5,972 \mathrm{Ca}$} & \multicolumn{2}{|l|}{$7,536 \mathrm{Aa}$} & \\
\hline Row + interrow & $6,946 \mathrm{Ba}$ & \multicolumn{3}{|c|}{$5,884 \mathrm{Ca}$} & \multicolumn{2}{|l|}{$7,935 \mathrm{Aa}$} & \\
\hline Broadcast & $4,822 \mathrm{ABb}$ & & $4,174 \mathrm{~B} \mathrm{~b}$ & & $5,468 \mathrm{Ab}$ & & \\
\hline \multirow[t]{2}{*}{ Means } & $6,166 \mathrm{~B}$ & & \multicolumn{2}{|l|}{$5,110 \mathrm{C}$} & \multicolumn{2}{|l|}{$7,031 \mathrm{~A}$} & \\
\hline & $B b$ & $B d$ & $\mathrm{Br}$ & & BRS 330 & DKB 551 & \\
\hline Monoculture & $13,101 \mathrm{~A}$ & $9,745 \mathrm{~B}$ & $13,826 \mathrm{~A}$ & & $1,057 \mathrm{C}$ & $1,114 \mathrm{C}$ & \\
\hline \multirow{3}{*}{$\begin{array}{l}\text { Implantation } \\
\text { systems }\end{array}$} & \multicolumn{6}{|c|}{ Total crude protein $\left(\mathbf{k g} \cdot \mathrm{ha}^{-1}\right)$} & \multirow{3}{*}{ Mean } \\
\hline & & BRS 330 & & & DKB 551 & & \\
\hline & $B b$ & $B d$ & $B r$ & $B b$ & $B d$ & $B r$ & \\
\hline Row & $201^{* 1, * 2}$ & $156^{* 1, * 2}$ & $212^{\star 1,{ }^{\star} 2}$ & $196^{* 1, * 2}$ & $159^{* 1, * 2}$ & $213^{* 1, * 2}$ & $189 b$ \\
\hline Interrow & $288^{* 1, * 2}$ & $250^{* 1, * 2}$ & $389^{* 1, * 2}$ & $274^{* 1, * 2}$ & $242^{* 1, * 2}$ & $393^{* 1, * 2}$ & $304 a$ \\
\hline Row + interrow & $274^{* 1, * 2}$ & $242^{* 1, * 2}$ & $390^{* 1, * 2}$ & $275^{* 1, * 2}$ & $244^{* 1, * 2}$ & $391^{* 1, * 2}$ & $303 a$ \\
\hline \multirow[t]{2}{*}{ Broadcast } & $145^{* 1, * 2}$ & $132^{* 1, * 2}$ & $172^{* 1, * 2}$ & $144^{* 1, * 2}$ & $130^{* 1, * 2}$ & $171^{* 1, * 2}$ & $149 c$ \\
\hline & $B b$ & & \multicolumn{2}{|l|}{$B d$} & \multicolumn{2}{|l|}{$B r$} & \\
\hline Row & $198 A b$ & & \multicolumn{2}{|l|}{$158 A b$} & \multicolumn{2}{|l|}{$213 \mathrm{Ab}$} & \\
\hline Interrow & $281 \mathrm{Ba}$ & & \multicolumn{2}{|l|}{246} & $391 \mathrm{Aa}$ & & \\
\hline Row + interrow & $275 \mathrm{Ba}$ & & $243 \mathrm{Ba}$ & & $390 \mathrm{Aa}$ & & \\
\hline Broadcast & $144 \mathrm{Ac}$ & & $131 \mathrm{Ac}$ & & $171 \mathrm{Ac}$ & & \\
\hline Means & 222 B & & $193 \mathrm{~B}$ & & $291 \mathrm{~A}$ & & \\
\hline & $\mathrm{Bb}$ & $\mathrm{Bd}$ & $\mathrm{Br}$ & & BRS 330 & DKB 551 & \\
\hline Monoculture & $633 \mathrm{~B}$ & $517 \mathrm{C}$ & $787 \mathrm{~A}$ & & $49 \mathrm{D}$ & $53 \mathrm{D}$ & \\
\hline & & & Soil cc & $r(\%)$ & & & \\
\hline $\begin{array}{l}\text { Implantation } \\
\text { systems }\end{array}$ & & BRS 330 & & & DKB 551 & & Mean \\
\hline & $B b$ & $B d$ & $B r$ & $B b$ & $B d$ & $B r$ & \\
\hline Row & $90^{* 1}$ & $95^{* 1}$ & $95^{* 1}$ & $92^{* 1}$ & $90^{* 1}$ & $95^{* 1}$ & \\
\hline Interrow & $92^{* 1}$ & $92^{* 1}$ & $92^{* 1}$ & $92^{* 1}$ & $97^{* 1}$ & $95^{* 1}$ & \\
\hline Row + interrow & $97^{* 1}$ & $95^{* 1}$ & $97^{* 1}$ & $92^{* 1}$ & $92^{* 1}$ & $92^{* 1}$ & \\
\hline Broadcast & $92^{* 1}$ & $92^{* 1}$ & $95^{* 1}$ & $90^{* 1}$ & $95^{* 1}$ & $90^{* 1}$ & \\
\hline & $B b$ & $B d$ & $B r$ & BRS 330 & DKB 551 & & \\
\hline Monoculture & $100 \mathrm{~A}$ & $100 \mathrm{~A}$ & $100 \mathrm{~A}$ & $40 \mathrm{~B}$ & $50 \mathrm{~B}$ & & \\
\hline
\end{tabular}

*Means followed by the same letters, uppercase on the line and lowercase on the column, do not differ by the Tukey's test at $5 \%$ probability.

${ }^{* 1},{ }^{2}$ Means differ significantly by Dunnett's test at $5 \%$ probability in relation to sorghum and Brachiaria monocrops, respectively. 
in monocrop, since the dry matter yields in all combinations were higher than the respective sorghum monocrops (Table 4). This proves the importance of the contribution of biomass from Brachiaria in intercropping systems (REZENDE et al., 2016). The presence of higher dry matter values in the off-season provides advantages such as better conservation and physical quality of the soil and maintenance of soil moisture for a longer time (FLÁVIO NETO et al., 2015). These advantages become essential for the Cerrado region, a time when rainfall is limited to a certain time of the year. In addition, it is important to consider that the presence of a greater amount of dry matter on the soil surface contributes to greater suppression of emergence of weeds in the successor crop, that is, planted in the summer growing season (OLIVEIRA JUNIOR et al., 2014).

Among the species of Brachiaria grown in intercropping systems, a higher dry matter content is observed with the use of B. ruziziensis followed by B. brizantha and B. decumbens (Table 4). For the sustainability of the no-till system there is a need to produce $6 \mathrm{t} \cdot \mathrm{ha}^{-1}$ residues on the soil surface (FERREIRA et al., 2010), a result obtained with B. ruziziensis and B. brizantha. Therefore, these species proved to be more suitable for supplying dry matter in the off-season, after harvesting annual crops.

The dry matter yields of the intercropping system were lower than those of the Brachiaria monocrop (Table 4). This is because in the intercrop there was a reduction in radiation reaching Brachiaria due to shading caused by sorghum plants. In this condition, the plant directs the reserve carbohydrates to the apical meristem in the search for light, decreasing the emergence of new tillers (TAIZ et al., 2017) and the accumulation of dry matter in the aerial part. In monocrop, Brachiaria plants were in free growth, without competition with another species, as in the intercrop. In this system, even with the lower dry matter yield compared to the monocrop of the respective Brachiaria, there is the production of grains, becoming another income option for the farmer in the off-season.

In monocrop, B. ruziziensis and B. brizantha produced larger amounts of dry matter, higher than $B$. decumbens (Table 4). This species in turn exceeded the values obtained with the sorghum hybrids in monocrop, proving the potential for dry matter production of the evaluated species. The higher production of dry matter by Brachiaria compared to sorghum is related, in addition to the genetic potential, to the longer period of plant growth (Fig. 1). This becomes important to increase the permanence of straw on the soil surface for planting the soybean crop at the beginning of the rainy season, since, in this phase, most agricultural areas of the Cerrados do not have vegetation cover on the soil surface.

The intercropping effects on total crude protein yield were similar to those observed for total dry matter yield (Table 4). The sowing systems of Brachiaria in the interrow and row + interrow of sorghum provided higher values in all intercropped species. For each system, higher values were observed with the use of B. ruziziensis sown in the interrow and row + interrow compared to the other species. In row and broadcast sowing systems, there were no significant differences between forage species.
The results of total crude protein obtained in the intercropping system again prove the advantage of intercropping sorghum with Brachiaria, since the values were higher in all treatments of intercrop in relation to the respective monocrops of sorghum hybrids, however, inferior to monocrops of Brachiaria (Table 4). In this case, the superior performance of $B$. ruziziensis stands out, followed by $B$. brizantha and $B$. decumbens thus overcoming sorghum hybrids, as observed by SILVA et al. (2014).

Another advantage of intercropping systems is related to vegetation cover on the soil surface. At the time of sorghum harvest, all treatments in the intercrop showed values above $90 \%$, being higher than in sorghum monocrops (Table 4). These results prove the benefits of the supply of dry matter in intercrop by Brachiaria plants. At the time of cutting the plants, the soil surface was completely covered, which provides benefits for soil conservation, such as protection against erosion and the impact of raindrops (IKEDA et al., 2007).

Agricultural systems have to be improved to minimize the environmental impacts of their agricultural practices, in addition to providing profitability to rural producers (IQBAL et al., 2019). The results indicate that intercropping grain sorghum with Brachiaria, in succession to soybean cultivation, becomes an excellent option for the production of grains and dry matter in the off-season under Cerrado conditions. In this system, even though there is a reduction in the yield of sorghum grains in certain situations, as previously discussed, there is the presence of Brachiaria in the off-season, whose biomass provides excellent soil cover and the production of dry matter with a higher $\mathrm{C} / \mathrm{N}$ ratio.

Further, dry matter produced in the off-season can be used for grazing cattle, a time when there is a shortage of forage in the field, or be desiccated to produce straw for the implantation of the summer crop. These facts become important for the study region, as the climatic conditions in this period make it difficult to maintain the straw on the soil surface. Therefore, the system proves to be a viable option for diversification of crops in the Cerrados region.

\section{CONCLUSIONS}

Brachiaria implantation systems provide a reduction in the yield of sorghum grains, with emphasis on the intercrop in the row, in the interrow and the broadcast sowing without, however, presenting differences between the hybrids in intercrop.

Brachiaria implantation systems in the interrow and row + interrow show a higher production of dry matter and total crude protein in the off-season, with emphasis on B. ruziziensis.

The DKB 551 hybrid is more sensitive to competition with Brachiaria plants.

Intercropping sorghum and Brachiaria is the most effective system to increase dry matter production and soil cover in the off-season. 
ACKNOWLEDGEMENTS: Not appliacable

FUNDING: Fundação de Amparo à Pesquisa do Estado de Goiás (201810267001505), Conselho Nacional de Desenvolvimento Científico e Tecnológico (305067/2012-5). This study was financed in part by the Coordenação de Aperfeiçoamento de Pessoal de Nível Superior - Brasil (CAPES) - Finance Code 001.

CONFLICTS OF INTEREST: All authors declare that they have no conflict of interest.

ETHICAL APPROVAL: Not applicable.

AVAILABILITY OF DATA AND MATERIAL: The datasets generated and/or analyzed during the current study are available from the corresponding author on reasonable request.

AUTHORS' CONTRIBUTIONS: Conceptualization: Silva, A.G. Data curation: Almeida, K.L. Formal analysis: Simon, G.A. Methodology: Costa, K.A.P. Writing - review \& editing: Sousa Junior, B.A.; Ferreira, C.J.B.

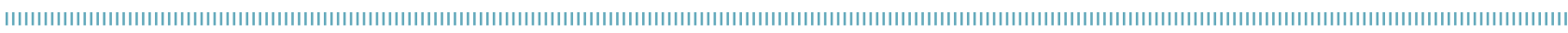
REFERENCES

ALVIM, M.J.; BOTREL, M.A.; XAVIER, D.F. As principais espécies de Brachiaria utilizadas no País (Comunicado Técnico 22). Juiz de Fora: Embrapa Gado e Leite, 2002. Available from: https:// ainfo.cnptia.embrapa.br/digital/bitstream/item/65321/1/ COT-22-As-principais-especies-de.pdf. Access on: 23 May 2019.

ANDREOTTI, M.; ARALDI, M.; Guimarães, V.F.; FURLANI JUNIOR, E.; BUZETTI, S. Produtividade do milho safrinha e modificações químicas de um Latossolo em sistema plantio direto em função de espécies de cobertura após calagem superficial. Acta Scientiarum. Agronomy, Maringá, v.30, n.1, p.109-115, 2008. https://doi. org/10.4025/actasciagron.v30i1.1158

BORGHI, E.; CRUSCIOL, C.A.C. Produtividade de milho, espaçamento e modalidade de consorciação com Braquiária brizantha em sistema plantio direto. Pesquisa Agropecuária Brasileira, Brasília, v.42, n.2, p.163-171, 2007. https://doi.org/10.1590/ S0100-204X2007000200004

BORGHI, E.; CRUSCIOL, C.A.C.; NASCENTE, A.S.; SOUSA, V.V.; MARTINS, P.O.; MATEUS, G.P.; COSTA, C. Sorghum grain yield, forage biomass production and revenue as affected by intercropping time. European Journal of Agronomy, Helsinki, v.51, p. 130-139, 2013. https://doi.org/10.1016/j.eja.2013.08.006

COMPANHIA NACIONAL DE ABASTECIMENTO (CONAB). Acompanhamento da Safra Brasileira de Grãos. 2012. Available from: https://www.conab.gov.br/info-agro/safras/graos/boletimda-safra-degraos/item/download/1262_54f29092624aa2bd 6e6b038e138d2ee4. Access on: 12 Jun. 2018.

CRISPIM, S.M.A.; BRANCO, O.D. Aspectos gerais das braquiárias e suas características na sub-região da Nhecolândia, Pantanal, MS (Boletim de Pesquisa e Desenvolvimento 33). Corumbá: Embrapa Pantanal, 2002. Available from: https://www.infoteca.cnptia.embrapa.br/ bitstream/doc/810752/1/BP33.pdf. Access on: 25 Mar. 2019.

DONEDA, A.; AITA, C.; GIACOMINI, S.J.; MIOLA, E.C.C.; GIACOMINI, D.A.; SCHIRMANN, J.; GONZATTO, R. Fitomassa e decomposição de resíduos de plantas de cobertura puras e consorciadas. Revista Brasileira de Ciência do Solo, Viçosa, v.36, n.6, p.1714-1723, 2012. https://doi.org/10.1590/SO100-06832012000600005
EMPRESA BRASILEIRA DEPESQUISA AGROPECUÁRIA (EMBRAPA). Manual de métodos de análise de solos. Rio de Janeiro: Embrapa Solos, 2017.

EMPRESA BRASILEIRA DEPESQUISA AGROPECUÁRIA (EMBRAPA). Sistema Brasileiro de Classificação de Solos. Rio de Janeiro: Embrapa Solos, 2018. 306p.

FERREIRA, A.C.B.; LAMAS, F.M.; CARVALHO, M.C.S.; SALTON, J.C.; SUASSUNA, N.D. Produção de biomassa por cultivos de cobertura do solo e produtividade do algodoeiro em plantio direto. Pesquisa Agropecuária Brasileira, Brasília, v.45, n.6, p.546-553, 2010. https://doi.org/10.1590/ so $100-204 \times 2010000600003$

FLÁVIO NETO, J.; SEVERIANO, E.C.; COSTA, K.A.P.; GUIMARÃES JUNNYOR, W.S.; GONÇALVES, W.G.; ANDRADE, R. Biological soil loosening by grasses from genus Brachiaria in crop-livestock integration. Acta Scientiarum. Agronomy, Maringá, v.37, n.3, p.375-383, 2015. https://doi.org/10.4025/actasciagron. v37i3.19392

GIACOMINI, S.J.; AITA, C.; VENDRUSCOLO, E.R.O.; CUBILLA, M.; NICOLOSO, R.S.; FRIES, M.R. Matéria seca, relação $\mathrm{C} / \mathrm{N}$ e acúmulo de nitrogênio, fósforo e potássio em misturas de plantas de cobertura de solo. Revista Brasileira de Ciência do Solo, Viçosa, v.27, n.2, p.325-334, 2003. https://doi.org/10.1590/ so $100-06832003000200012$

HENNIGH, D.S.; AL-KHATIB, K.; TUINSTRA, M.R. Response of acetolactate synthase-resistant grain sorghum to nicosulfuron plus rimsulfuron. Weed Technology, Fayetteville, v.24, n.4, p.411-415, 2010. https://doi.org/10.1614/ WT-D-09-00061.1

HORVATHY NETO, A.; SILVA, A.G.; TEIXEIRA, I.R.; COSTA, K.A.P.; ASSIS, R.L. Consórcio de Sorgo Granífero e Braquiária na Safrinha para Produção de Grãos e Forragem. Revista Caatinga, Mossoró, v.27, n.3, p.132-141, 2014. Available from: https://periodicos. ufersa.edu.br/index.php/caatinga/article/view/2832. Access on: 25 Mar. 2019. 
HORVATHY NETO, A.H.; SILVA, A.G.; TEIXEIRA, I.R.; SIMON, G.A.; ASSIS, R.L.; ROCHA, V.S. Consórcio sorgo e braquiária para produção de grãos e biomassa na entressafra. Revista Brasileira de Ciências Agrárias, Recife, v.7, p.743-749, 2012. Supplement. https://doi.org/10.5039/agraria.v7isa 1908

IKEDA, F.S.; MITJA, D.; VILELA, L.; CARMONA, R. Banco de sementes no solo em sistemas de cultivo lavoura-pastagem. Pesquisa Agropecuária Brasileira, Brasília, v.42, n.1 1, p.1545-1551, 2007. https://doi.org/10.1590/SO100-204X2007001100005

IQBAL, M.A.; HAMID, A.; AHMAD, T.; SIDDIQUI, M.H.; HUSSAIN, I.; ALI, S.; ALI, A.; AHMAD, Z. Forage sorghum-legumes intercropping: effect on growth, yields, nutritional quality and economic returns. Bragantia, Campinas, v.78, n.1, p.82-95, 2019. https://doi. org/10.1590/1678-4499.2017363

MAGALHÃES, P.C.; SILVA, J.B.; DURAES, F.O.M.; RIBEIRO, L.S. Fitotoxicidade causada por herbicidas na fase inicial de desenvolvimento da cultura do sorgo. Planta Daninha, Viçosa, v.18, n.3, p.483-490, 2000. https://doi.org/10.1590/ S0100-83582000000300014

MALAVOLTA, E.; VITTI, G.C.; OLIVEIRA, S.A. Avaliação do estado nutricional de plantas: princípios e aplicações. Piracicaba: Associação Brasileira para Pesquisa da Potassa e do Fosfato, 1997. 319p.

OLIVEIRA JUNIOR, R.S.; RIOS, F.A.; CONSTANTIN, J.; ISHIIIWAMOTO, E.L.; GEMELLI, A.; MARTINI, P.E. Grass straw mulching to suppress emergence and early growth of weeds. Planta Daninha, Viçosa, v.32, n.1, p.11-17, 2014. https://doi.org/10.1590/ SO $100-83582014000100002$

OLIVEIRA, S.M.; FAVARIN, J.L.; ALMEIDA, R.E.M. Nitrogênio no consórcio entre milho e braquiária. A Granja, Porto Alegre, v.73, n.824, p.65-67, 2017.
REZENDE, B.P.M.; JAKELAITIS, A.; TAVARES, C.J.; MARANGONI, R.E.; CUNHA, P.C.R. Consórcio de sorgo com espécies forrageiras. Revista Agro@mbiente, Boa Vista, v.10, n.1, p.57-64, 2016. https://doi.org/10.18227/1982-8470ragro. v10i1.3052

RIBEIRO, M.G.; COSTA, K.A.P.; SILVA, A.G.; SEVERIANO, E.C.; SIMON, G.A.; CRUVINEL, W.S.; SILVA, V.R.; SILVA, J.T. Grain sorghum intercropping with Brachiaria brizantha cultivars in two sowing systems as a double crop. African Journal of Agricultural Research, Ago-Iwoye, v. 10, n.39, p.3759-3766, 2015. Available from: https://academicjournals.org/ journal/AJAR/article-abstract/E09464755574. Access on: 23 Mar. 2019.

SANTOS, L.C.; BONOMO, P.; SILVA, V.B.; PATÊS, N.M.S.; SILVA, C.C.F.; PIRES, A.J.V. Características morfogênicas de Braquiárias em resposta a diferentes adubações. Acta Scientiarum. Agronomy, Maringá, v.31, n.2, p.221-226, 2009. https://doi.org/10.4025/ actasciagron.v31i2.7032

SILVA, A.G.; MORAES, L.E.; HORVATHY NETO, A.; TEIXEIRA, I.R.; SIMON, G.A. Consórcio sorgo e braquiária na entrelinha para produção de grãos, forragem e palhada na entressafra. Revista Ceres, Viçosa, v.61, n.5, p.697-705, 2014. https://doi. org/10.1590/0034-737X201461050013

SILVA, A.G.; FRANCISCHINI, R.; GOULART, M.M.P. Desempenho agronômico e econômico de híbridos de sorgo granífero na safrinha em Montividiu-GO. Revista de Agricultura, Piracicaba, v.90, n.1, p.17-30, 2015. https://doi.org/10.37856/bja. v90i 1.117

TAIZ, L.; ZEIGER, E.; MøLLER, M.; MURPHY, A. Fisiologia e Desenvolvimento Vegetal. Porto Alegre: Artmed, 2017. 888p. 